\title{
Vein donor site morbidity after coronary bypass surgery: An overlooked but important issue
}

\author{
Geoffrey G Hallock MD \\ Division of Plastic Surgery, The Lehigh Valley Hospital, Allentown, Pennsylvania, USA
}

\section{GG Hallock. Vein donor site morbidity after coronary bypass surgery: An overlooked but important issue. Can J Plast Surg 1999;7(3):117-121.}

Leg morbidity after harvest of veins for coronary artery bypass grafts (CABG) is a significant and under-recognized problem. Although it is not usually life-threatening compared with mediastinal wound infections, the absolute number of limb complications reported annually in North America is approximately double the rate of sternal wound infections. A review of the data in the Cardiac Registry at The Lehigh Valley Hospital (Allentown, Pennsylvania) for 4880 CABG patients from the past five years showed that sternal infections occurred in 48 patients (1\%) compared with a reported lower limb morbidity in $31(0.6 \%)$ hospitalized patients. This substantiates the point that morbidity is an important problem, especially if limb-threatening. Whereas many surgical protocols have been established for the treatment of mediastinal infections, there has been virtually no discussion on the management of the problematic donor limb. Plastic surgery consultation in this hospital was requested for only five (16\%) patients with leg wounds, whereas it was the norm for the majority of sternal wounds (42 [87.5\%]). Minimal debridement and expectant healing was the most common approach for these lower extremity wounds. An acceptable vascular profile in these patients, who often have coexistent atherosclerotic peripheral vascular disease, should be an initial priority. In those with limb complications, this had often been overlooked preoperatively. Because the failure of a wound to heal can result in limb amputation, early intervention by plastic surgeons must be emphasized.

Key Words: Coronary bypass; Donor site leg morbidity; Saphenous vein grafts; Sternal wound infection

\section{Morbidité au site de prélèvement veineux chez les patients après un pontage aorto-coronarien : un sujet négligé mais important}

RÉSUMÉ : La morbidité à la jambe après un prélèvement veineux en vue d'un pontage aorto-coronarien par greffe est un problème important mais méconnu. Bien que cette morbidité ne représente généralement pas une menace pour la vie comparativement aux infections des plaies médiastinales, le nombre absolu de complications aux membres rapporté annuellement en Amérique du Nord est environ deux fois plus élevé que celui des infections des plaies sternales. Une revue des données dans le registre cardiaque au Lehigh Valley Hospital (Allentown, Pennsylvanie) sur 4880 patients ayant subi des pontages aorto-coronariens dans les cinq dernières années a démontré que des infections sternales sont survenues chez 48 patients ( $1 \%$ ) comparativement à une morbidité du membre inférieur rapportée chez 31 ( $0,6 \%)$ patients hospitalisés. Ceci prouve que la morbidité est un problème important, particulièrement si elle menace la survie du membre. Tandis que de nombreux protocoles chirurgicaux ont été établis pour le traitement des infections médiastinales, il n’y a pour ainsi dire eu aucune discussion sur la prise en charge des complications au site de prélèvement veineux. Une consultation en chirurgie plastique dans cet hôpital a été demandée chez seulement cinq (16\%) des patients présentant des plaies aux jambes, alors que c'était la norme pour la majorité des plaies sternales (42 [87,5\%]). Un débridement minimal et un espoir de cicatrisation représentaient les approches les plus courantes pour ces plaies des membres inférieurs. Un profil vasculaire acceptable chez ces patients, qui sont souvent atteints d'une maladie vasculaire périphérique athéroscléreuse concomitante, devrait être une priorité initiale. Chez les patients qui présentent des complications aux membres, cette question a souvent été négligée avant l'opération. Parce que l'échec de la cicatrisation d'une plaie peut signifier l'amputation du membre, l'intervention précoce des chirurgiens plasticiens est d'une importance primordiale.

$\mathrm{T}$ he management of sternal wound complications after median sternotomy has been revolutionized by aggressive debridement protocols and muscle flap transposition (1).

Correspondence: Dr GG Hallock, 1230 South Cedar Crest Blvd, Suite 306, Allentown, Pennsylvania 18103, USA. Telephone 610-435-7555, fax 610-770-6390
The potentially lethal sequela of cardiac surgery has focused the attention of plastic surgeons almost exclusively on refinements in treating such chest wounds $(1,2)$. According to the National Cardiac Surgery Database (1994), deep sternal infection rates in first-operation coronary artery bypass graft (CABG) patients was $0.5 \%$ (3), which in any large medical centre with an active cardiothoracic service is a large number 
TABLE 1

Comparison of observed morbidities after CABG

\begin{tabular}{lccc}
\hline Year & $\begin{array}{c}\text { Number of patients } \\
\text { undergoing CABG }\end{array}$ & $\begin{array}{c}\text { Sternal } \\
\text { infections }\end{array}$ & $\begin{array}{c}\text { Donor leg } \\
\text { morbidity }\end{array}$ \\
\hline 1992 & 1051 & 14 & 13 \\
1993 & 911 & 7 & 8 \\
1994 & 908 & $8^{*}$ & $4^{*}$ \\
1995 & 957 & 6 & 1 \\
1996 & 1053 & $13^{*}$ & $5^{*}$ \\
Total & 4880 & $48(1 \%)$ & $31(0.6 \%)$ \\
\hline
\end{tabular}

Data tabulated from The Lehigh Valley Hospital Cardiac Registry. *One patient had concomitant sternal and leg infections. CABG Coronary artery bypass graft

TABLE 2

Methods of treatment of vein graft donor leg complications

\begin{tabular}{lc}
\hline Treatment & Number of Patients \\
\hline Expectant local care & 28 \\
Simple reclosure & 1 \\
Skin graft & 1 \\
Flaps & \\
$\quad$ Local skin & 0 \\
$\quad$ Local muscle & 0 \\
$\quad$ Free flap & 0 \\
Limb amputation & 1 \\
Total reported complications & 31 \\
Plastic surgery consultations & $5(16 \%)$ \\
\hline
\end{tabular}

From data reported in The Lehigh Valley Hospital Cardiac Registry for 1992 to 1996

of patients. Interestingly, morbidity of the lower extremity vein graft donor site was found to be approximately twice as high (3), yet there are few guidelines for the treatment of this more common problem, which can be limb-threatening or potentially life-threatening if sepsis is not controlled (4-6). Early, aggressive management of lower limb wound healing problems associated with CABG patients, preferably by wound care specialists following an established protocol, is highly recommended (4).

\section{PATIENTS AND METHODS}

A retrospective review of the Cardiac Surgery Registry at The Lehigh Valley Hospital (Allentown, Pennsylvania) was undertaken for the last five complete years available (1992 to 1996). The annual number of patients who underwent CABG using autogenous saphenous vein grafts was recorded as well as the incidence of sternal wound infection and any lower extremity donor site morbidity (Table 1). All patients who had a plastic surgery consultation were identified, and methods used to achieve adequate healing of the donor leg were tabulated (Table 2).
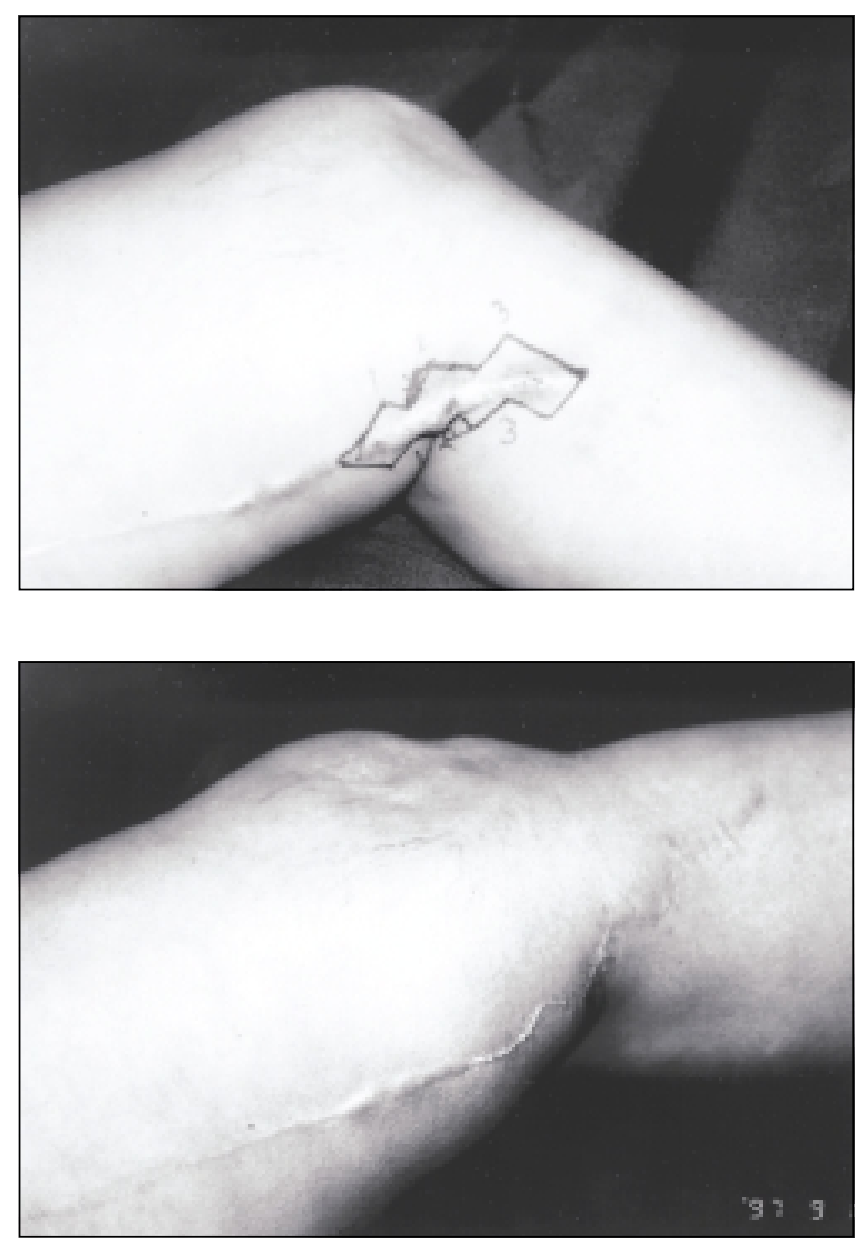

Figure 1) Top A hypertrophic, unstable scar contracture formed across the knee joint following saphenous vein procurement from the medial left thigh. This late complication was a nuisance and a functional concern. Planned revision by w-plasty was marked. Bottom W-plasty eliminated the contracture to allow full knee extension, which permitted a healed incision and a superior aesthetic result

\section{RESULTS}

During the study period from 1992 to 1996, The Lehigh Valley Hospital maintained one of the busiest (by volume) cardiothoracic surgery services in the state of Pennsylvania. A total of 4880 patients underwent $\mathrm{CABG}$ via median sternotomy. A deep sternal wound infection occurred in $48(1 \%)$ patients (Table 1), and the majority of these patients (42 [87.5\%]) had a plastic surgery consultation for the requisite debridement, local care or muscle flap coverage.

A standard open-extended medial thigh and/or leg incision was employed to obtain autogenous saphenous vein grafts. Lower extremity morbidity was only recorded if it occurred during the patient's initial or subsequent hospitalization and was less than that involving chest wounds $(0.6 \%)$, but this was admittedly incomplete because the Cardiac Registry did not include out-patient data where most of these may present as late problems (Figure 1). Only infrequently (five [16\%]) was an in-patient plastic surgery consultation sought, usually only when widespread tissue destruction was a prelude to potential limb loss. 

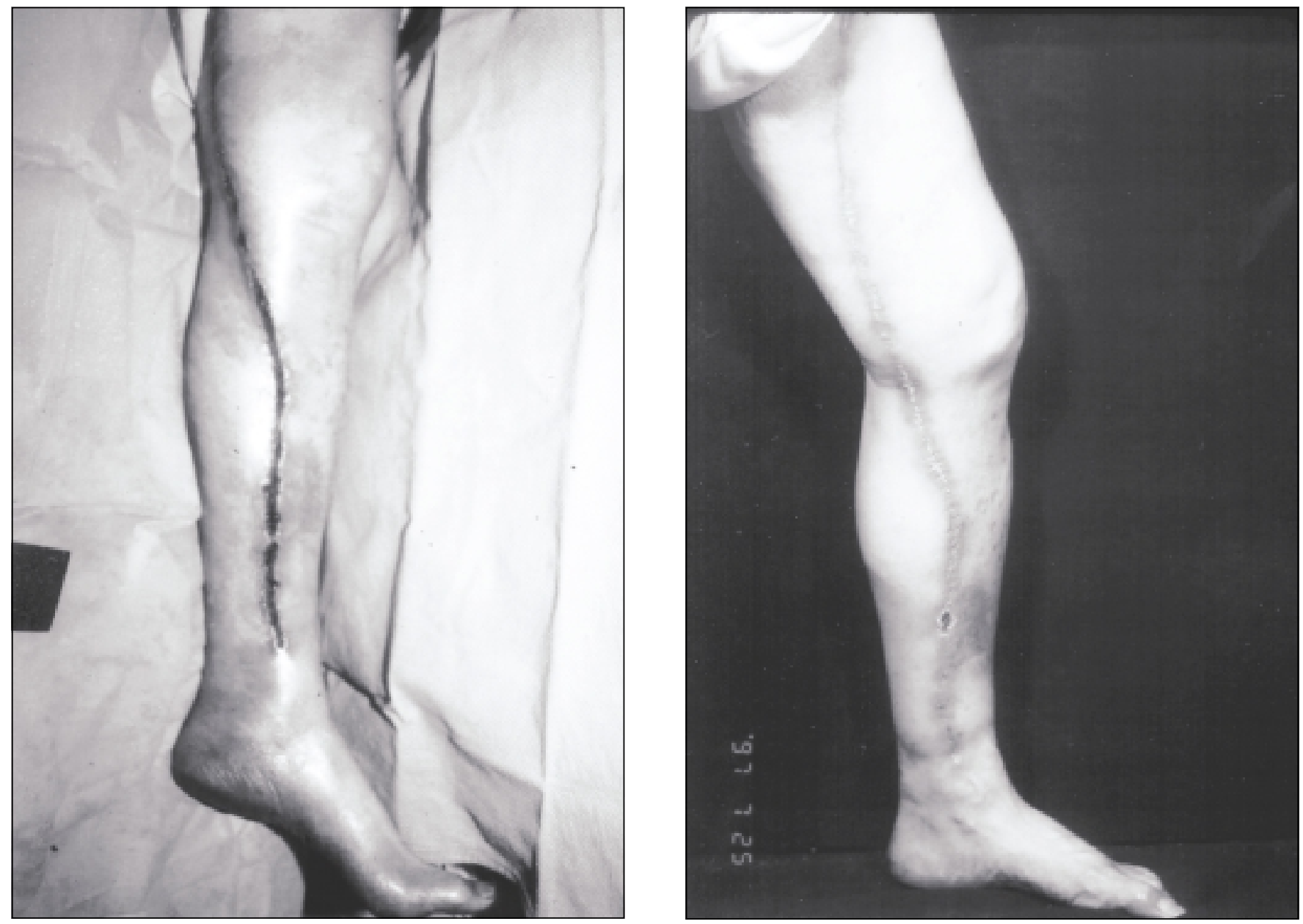

Figure 2) Left Minimal skin edge necrosis along the entire incision following a traditional 'open' left lower extremity greater saphenous vein harvest. Right After ascertaining the presence of an acceptable vascular profile, debridement with tension-free direct reapproximation of the surrounding redundant skin accelerated healing

The first step in intervention was an assessment of the patient's vascular profile to ensure re-establishing normal perfusion to the donor extremity. Simple debridement of necrotic tissue, antibiotics when indicated and delayed healing by contraction was the most common approach (Table 2). Secondary closure of the donor site incision was done immediately after debridement only if remaining skin redundancy permitted tension-free healing (Figure 2). In no cases were acute or chronic skin stretching methods used, which may compromise the vascularity of the marginally viable surrounding skin.

Larger defects required skin grafts (Figure 3) or, if the wound bed was inhospitable, some form of vascularized flap was necessary, although none were used during this specific time frame. Limb amputation was required in one case where attempts to induce wound healing were unsuccessful.

\section{DISCUSSION}

The impact on overall outcomes of traditional saphenous vein harvesting methods for coronary artery revascularization has been overshadowed by the risk of death from sternal wound complications. However, leg-related problems can also contribute to significant morbidity and result in lengthier hospital stays, function loss, pain and suffering, and, to some most important, greater costs (4). These leg problems have included cellulitis, hematomas or seromas, chronic edema, saphenous neuralgia and ischemic limb sequela, with an incidence ranging from $1 \%$ to $40 \%(4,7,8)$. Many occur late in the out-patient setting, often escaping inclusion in the Cardiac Registry, which explains why the incidence of leg complications in our patients was lower than that reported nationally (3) but still a major issue. An example of this is the hypertrophic or unstable scar (Figure 1), where scar revision by the plastic surgeon is important.

Known preoperative risk factors include diabetes mellitus, obesity, female sex and atherosclerotic peripheral vascular disease, which often coexists with coronary artery disease and must always be ruled out as the culprit for any postoperative wound breakdown (7). Bridge dissection techniques (9), use of multiple small incisions or minimally invasive vein harvest using an endoscope via a single access incision can decrease the rate of wound infection, diminish wound care re- 

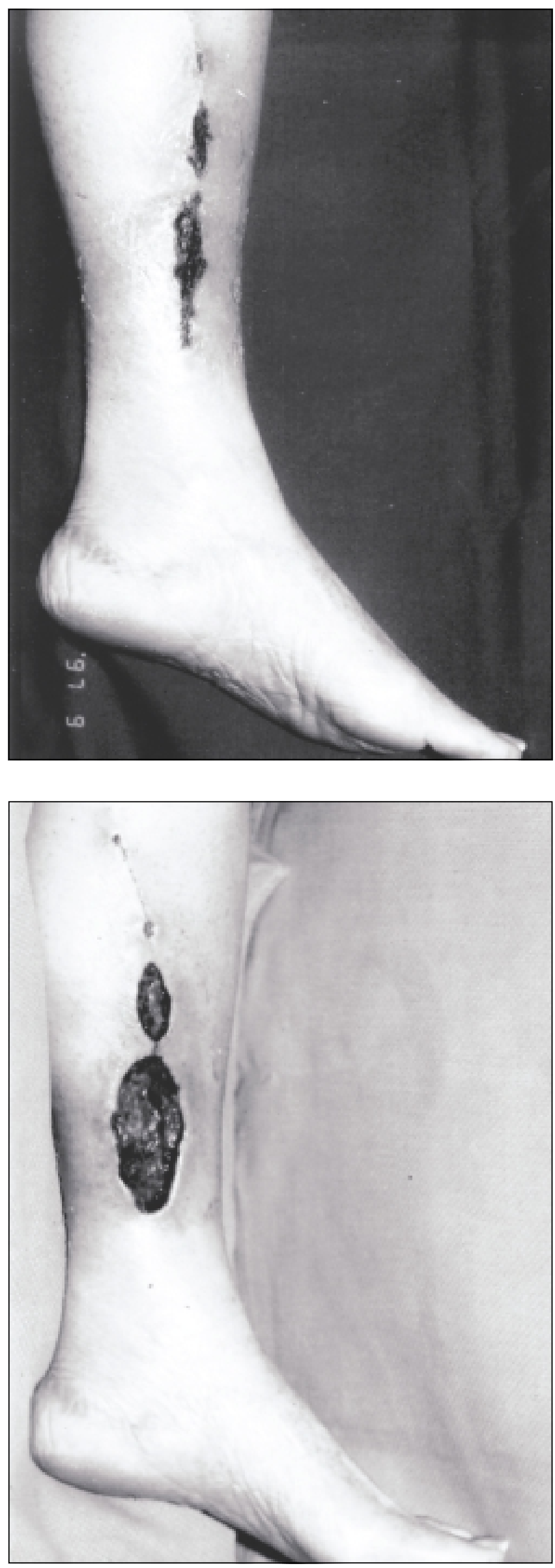

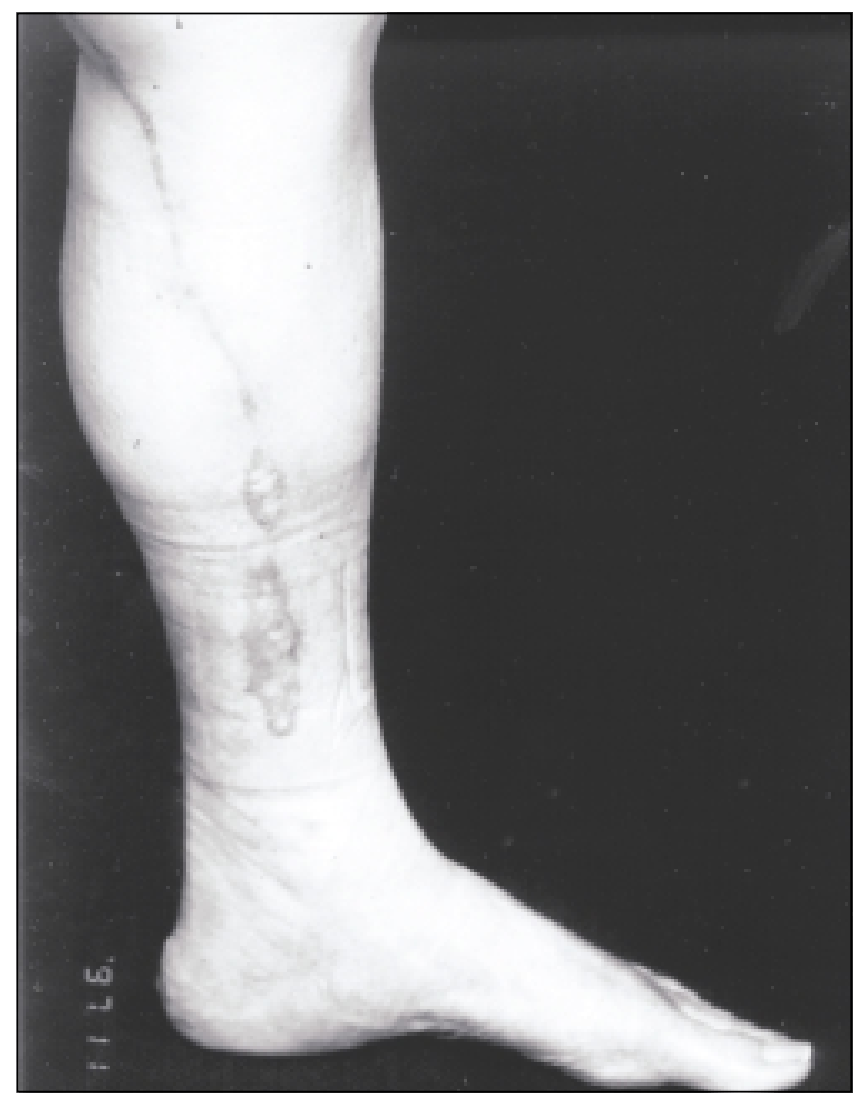

Figure 3) Top left Localized cellulitis surrounding the eschar at this distal left leg vein graft donor site compounded the problem with progressive tissue loss. Bottom left After serial debridement, a wound too large for further conservative treatment remained. Above Adequate granulations developed to allow skin grafting that hastened ultimate wound healing

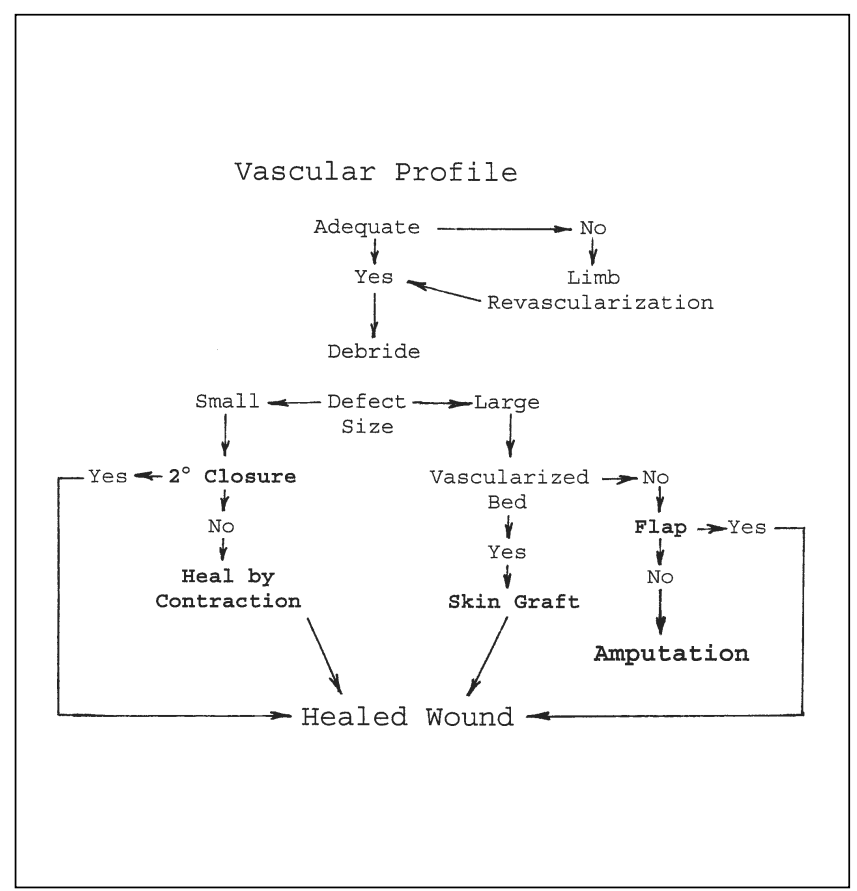

Figure 4) A basic protocol for management of the compromised lower extremity coronary artery bypass vein graft donor site 
quirements, permit earlier ambulation and, from a cosmetic standpoint, result in smaller scars $(7,8,10,11)$. Unfortunately, long term vessel patency rates for veins procured by this last method have not been definitively established $(8,9)$.

Although plastic surgery consultation typically is delayed in our centre until there is significant tissue necrosis, guidelines for basic wound management have been established that can be followed by any wound care specialist (Figure 4). The peripheral circulation must first be optimized, otherwise the risk of limb loss is substantial, regardless of the subsequent treatment. Progressive tissue loss in a failed wound commonly follows the onset of a low grade, localized infection of any necrotic eschar, and can be avoided by early and

\section{REFERENCES}

1. Hugo NE, Sultan MR, Ascherman JA, Patsis MC, Smith CR, Rose EA. Single-stage management of 74 consecutive sternal wound complications with pectoralis major myocutaneous advancement flaps. Plast Reconstr Surg 1994;93:1433-41.

2. Nahai F, Rand RP, Hester TR, Bostwick J 3rd, Jurkiewicz MJ. Primary treatment of the infected sternotomy wound with muscle flaps: a review of 211 consecutive cases. Plast Reconstr Surg 1989;84:434-41.

3. National Cardiac Surgery Database. The Society for Thoracic Surgeons, Fax Alert. Cardiology Preeminence Roundtable. April 20, 1994.

4. Delaria GA, Hunter JA, Goldin MD, Serry C, Javid H, Najafi H. Leg wound complications associated with coronary revascularization. J Thorac Cardiovasc Surg 1981;81:403-7.

5. Lee KS, Reinstein L. Lower limb amputation of the donor site extremity after coronary artery bypass grafting surgery. Arch Phys Med Rehabil 1986;67:564-5.

6. Lavee J, Schneiderman J, Yorav S, Shewatch-Millet M, Adar R. aggressive debridement. More often than not, only local care is then needed, with healing by contraction or occasionally by direct skin reapproximation (Figure 2). The neglected wound may become too large or too deep for salvage, even with a skin graft or vascularized flap. Ideally, the input of plastic surgeons should be sought at the time of initial recognition of the problem and not delayed until limb amputation may be the only solution. The key to consistent success with the comprised donor leg wound associated with CABG is early, aggressive treatment. This has already been established as the norm for the compromised sternal wound $(1,2)$.

ACKNOWLEDGEMENTS: Data were obtained from the Cardiac Registry at The Lehigh Valley Hospital, Allentown, Pennsylvania.

Complications of saphenous vein harvesting following coronary artery bypass surgery. J Cardiovasc Surg 1989;30:989-91.

7. Cable DG, Dearani JA. Endoscopic saphenous vein harvesting: minimally invasive video-assisted saphenectomy. Ann Thorac Surg 1997;64:1183-5.

8. Connolly MW. Endoscopic subcutaneous saphenous vein harvest: lessions learned from 350 cases. Third Annual New York Symposium on Vascular and Endovascular Techniques. New York, September 6, 1997.

9. Meldrum-Hanna W, Ross D, Johnson D, Deal C. An improved technique for long saphenous vein harvesting for coronary revascularization. Ann Thorac Surg 1986;42:90-2.

10. Allen KB, Shaar CJ. Endoscopic saphenous vein harvesting. Ann Thorac Surg 1997;64:265-6.

11. Hallock GG, Rice DC. An endoscopic subcutaneous dissector for obtaining vein grafts. Ann Plast Surg 1998;41:595-9. 